
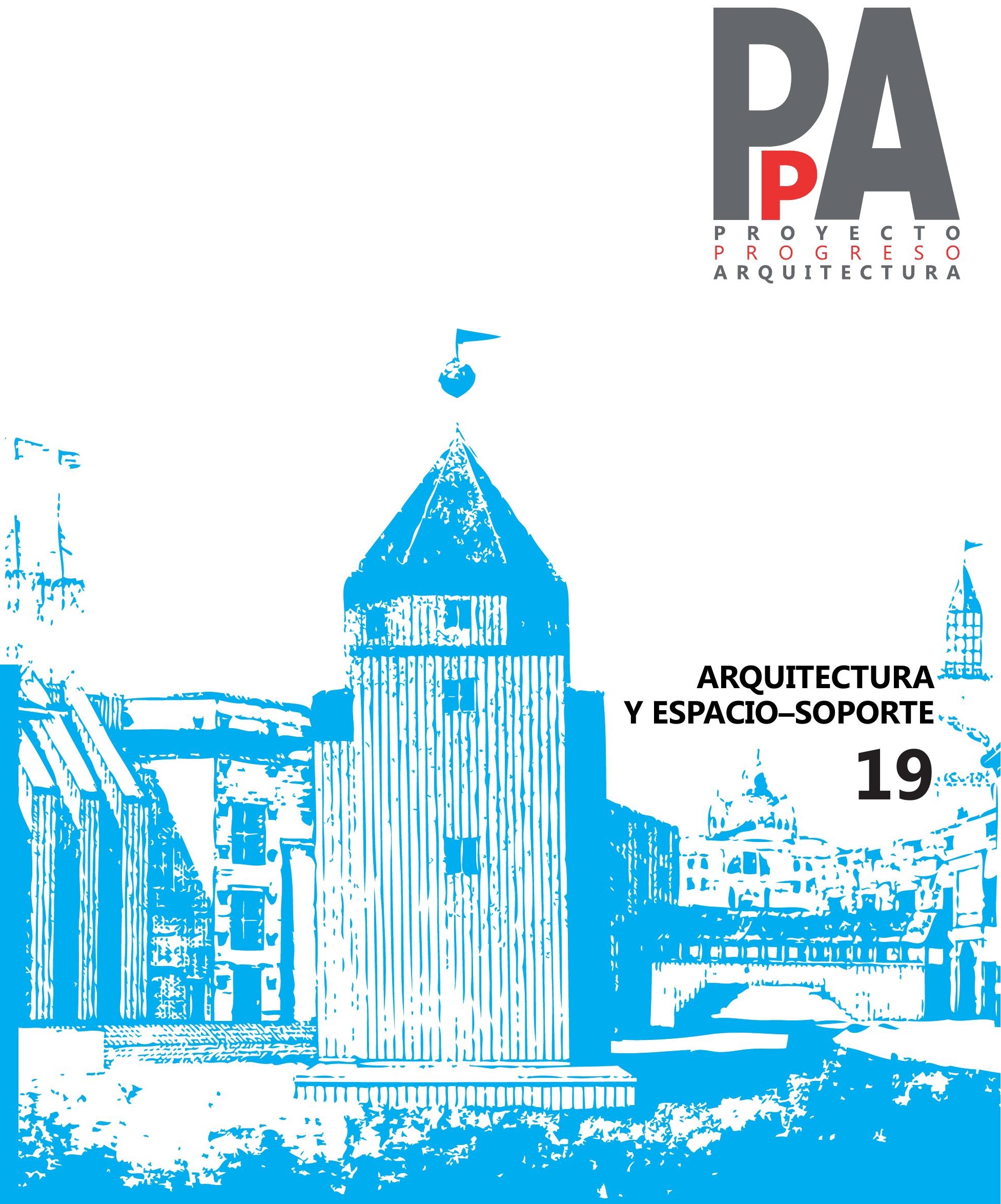


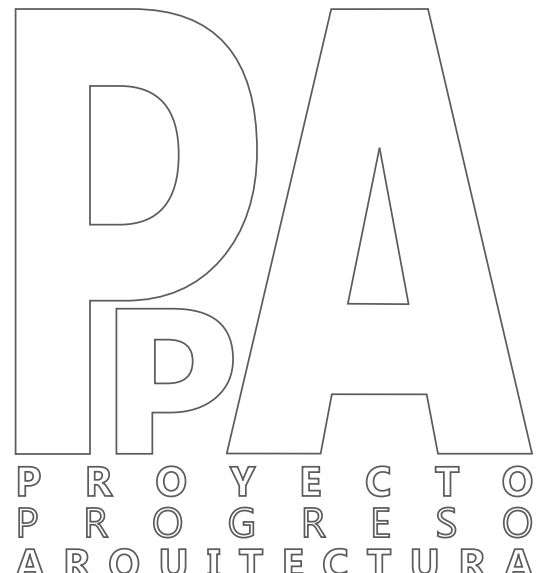

\section{ARQUITECTURA Y ESPACIO-SOPORTE 19}

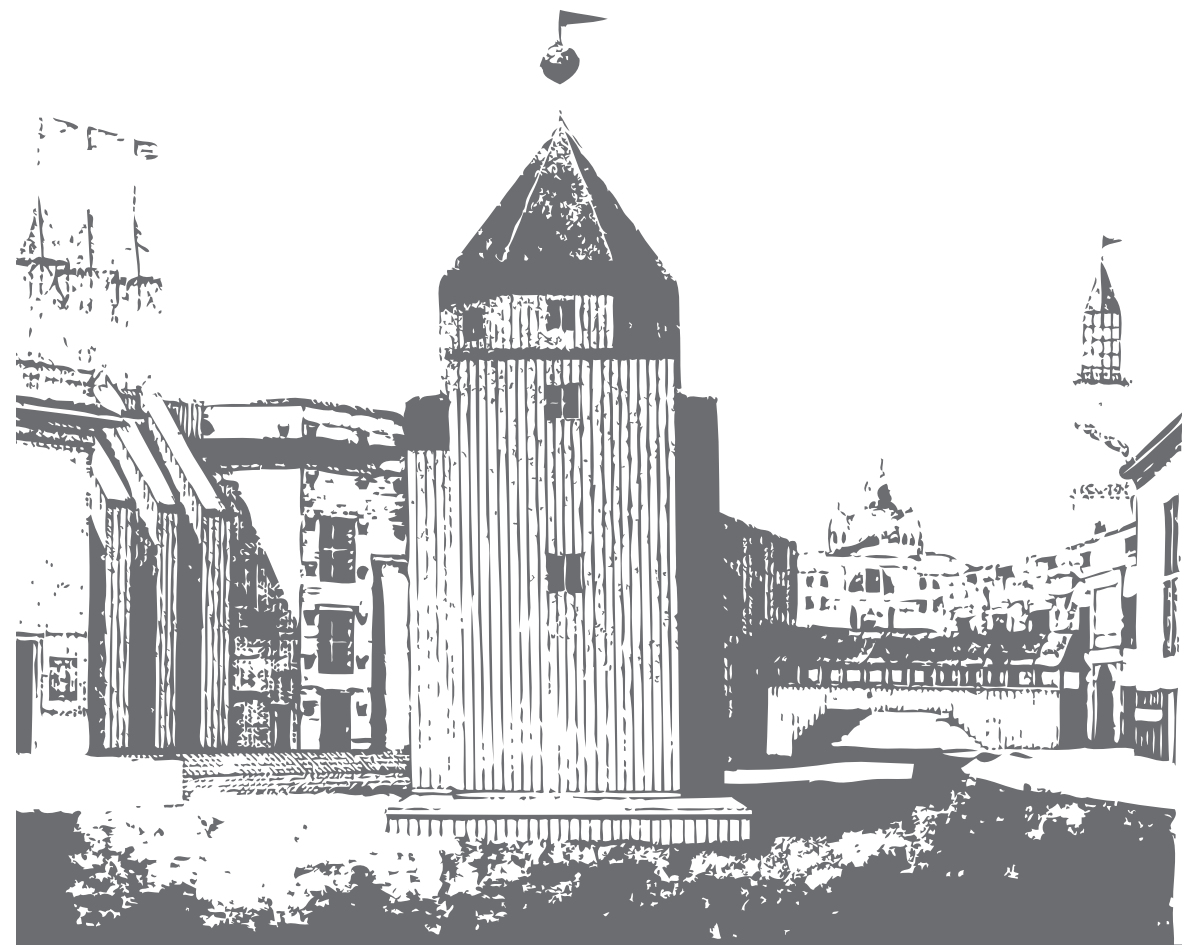

EDITORIAL UNIVERSIDAD DE SEVILLA AÑO 2018. ISSN 2171-6897 ISSNe 2173-1616 DOI: http://dx.doi.org/10.12795/ppa 



\section{REVISTA PROYECTO PROGRESO ARQUITECTURA}

\section{N519}

\section{arquitectura y espacio-soporte}
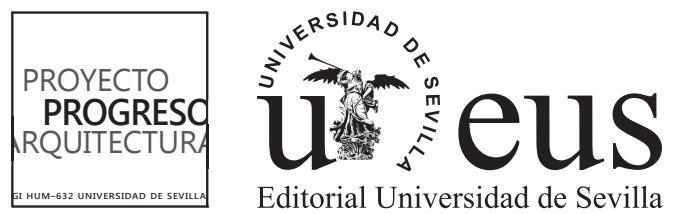


\section{arquitectura y espacio-soporte}

\section{DIRECCIÓN}

Dr. Amadeo Ramos Carranza. Escuela Técnica Superior de Arquitectura. Universidad de Sevilla.

\section{SECRETARIA}

Dr. Rosa María Añón Abajas. Escuela Técnica Superior de Arquitectura. Universidad de Sevilla.

\section{EQUIPO EDITORIAL}

\section{Edición:}

Dr. Rosa María Añón Abajas. Escuela Técnica Superior de Arquitectura. Universidad de Sevilla. España.

Dr. Miguel Ángel de la Cova Morillo-Velarde. Escuela Técnica

Superior de Arquitectura. Universidad de Sevilla. España.

Juan José López de la Cruz. Escuela Técnica Superior de

Arquitectura. Universidad de Sevilla. España.

Dr. Germán López Mena. Escuela Técnica Superior de Arquitectura.

Universidad de Sevilla. España.

Dr. Francisco Javier Montero Fernández. Escuela Técnica Superior de Arquitectura. Universidad de Sevilla. España.

Guillermo Pavón Torrejón. Escuela Técnica Superior de Arquitectura.

Universidad de Sevilla. España.

Dr. Alfonso del Pozo Barajas. Escuela Técnica Superior de

Arquitectura. Universidad de Sevilla. España.

Dr. Amadeo Ramos Carranza. Escuela Técnica Superior de

Arquitectura. Universidad de Sevilla. España.

Asesores externos a la edición:

Dr. Alberto Altés Arlandis. Post-Doctoral Research Fellow. Architecture

Theory Chair . Department of Architecture. TUDelft. Holanada

Dr. José Altés Bustelo. Escuela Técnica Superior de Arquitectura.

Universidad de Valladolid. España.

Dr. José de Coca Leicher. Escuela de Arquitectura y Geodesia.

Universidad de Alcalá de Henares. España.

Dr. Jaume J. Ferrer Fores. Escola Tècnica Superior d'Arquitectura de

Barcelona. Universitat Politècnica de Catalunya. España.

Carlos Arturo Bell Lemus. Facultad de Arquitectura. Universidad del

Atlántico. Colombia.

Carmen Peña de Urquía, architect en RSH-P. Londres. Reino Unido.

Dra. Marta Sequeira. CIAUD, Faculdade de Arquitectura da

Universidade de Lisboa, Portugal.

SECRETARÍA TÉCNICA

Gloria Rivero Lamela, arquitecto. Becaria Personal Investigador en Formación. Universidad de Sevilla. España.

MAQUETA DE LA PORTADA

Miguel Ángel de la Cova Morillo-Velarde

DISEÑO GRÁFICO DE LA MAQUETACIÓN

Maripi Rodríguez

MAQUETACIÓN DE LA PORTADA

Álvaro Borrego Plata

ISSN-ed. impresa: 2171-6897

ISSN-ed. electrónica: 2173-1616

DOI: http://dx.doi.org/10.12795/ppa

DEPÓSITO LEGAL: SE-2773-2010

PERIOCIDAD DE LA REVISTA: MAYO Y NOVIEMBRE

IMPRIME: PODIPRINT
COORDINADORES DE LOS CONTENIDOS DEL NÚMERO

Dr. Rosa María Añón Abajas. Escuela Técnica Superior de Arquitectura. Universidad de Sevilla.

Dr. Amadeo Ramos Carranza. Escuela Técnica Superior de Arquitectura. Universidad de Sevilla.

COMITÉ CIÉNTIFICO

Dr. Gonzalo Díaz Recaséns. Catedrático Proyectos Arquitectónicos. Escuela

Técnica Superior de Arquitectura. Universidad de Sevilla. España.

Dr. José Manuel López Peláez. Catedrático Proyectos Arquitectónicos.

Escuela Técnica Superior de Arquitectura. Universidad Politécnica de Madrid

España.

Dr. Víctor Pérez Escolano. Catedrático Historia, Teoría y Composición

Arquitectónicas. Escuela Técnica Superior de Arquitectura. Universidad de

Sevilla. España.

Dr. Jorge Torres Cueco. Catedrático Proyectos Arquitectónicos. Escuela

Técnica Superior de Arquitectura. Universitat Politècnica de València. España.

Dr. Armando Dal'Fabbro. Professore Associato. Dipartimento di

progettazione architettonica, Facoltà di Architettura, Universitat Instituto

Universitario di Architettura di Venezia. Italia.

Dr. Anne-Marie Chatelêt. Professeur Titulaire. Histoire et Cultures

Architecturales. École Nationale Supérieure d'Architecture de Stragbourg.

Francia.

EDITA

Editorial Universidad de Sevilla.

LUGAR DE EDICIÓN

Sevilla.

DIRECCIÓN CORRESPONDENCIA CIENTÍFICA

E.T.S. de Arquitectura. Avda Reina Mercedes, nº 2 41012-Sevilla.

Amadeo Ramos Carranza, Dpto. Proyectos Arquitectónicos.

e-mail: revistappa.direccion@gmail.com

\section{EDICIÓN ON-LINE}

Portal informático https://revistascientificas.us.es/index.php/ppa

Portalinformático G.I.HUM-632 http://www. proyectoprogresoarquitectura.com

Portal informático Editorial Universidad de Sevilla http://www.editorial.us.es/

(c) EDITORIAL UNIVERSIDAD DE SEVILLA, 2017.

Calle Porvenir, 27. 41013 SEVILLA. Tfs. 954487447 / 954487451

Fax954487443. [eus4@us.es] [http://www.editorial.us.es]

(c) TEXTOS: SUS AUTORES, 2017.

(c) IMÁGENES: SUS AUTORES Y/O INSTITUCIONES, 2017.

SUSCRIPCIONES, ADQUISICIONES Y CANJE revista PROYECTO, PROGRESO, ARQUITECTURA

Editorial Universidad de Sevilla.

Calle Porvenir, 27. 41013 SEVILLA. Tfs. 954487447 / 954487451

Fax 954487443

Reservados todos los derechos. Ni la totalidad ni parte de esta revista puede reproducirse o transmitirse por ningún procedimiento electrónico o mecánico, incluyendo fotocopia, grabación magnética o cualquier almacenamiento de información y sistema de recuperación, sin permiso escrito de la Editorial Universidad de Sevilla.

Las opiniones y los criterios vertidos por los autores en los artículos firmados son responsabilidad exclusiva de los mismos.
INICIATIVA DEL GRUPO DE INVESTIGACION HUM-632

"PROYECTO, PROGRESO, ARQUITECTURA"

http://www. proyectoprogresoarquitectura.com
COLABORA DEPARTAMENTO DE PROYECTOS ARQUITECTÓNICOS Escuela Técnica Superior de Arquitectura. Universidad de Sevilla. http://www.departamento.us.es/dpaetsas 


\section{revista PROYECTO, PROGRESO, ARQUITECTURA}

Nuestra revista, fundada en el año 2010, es una iniciativa del Grupo de Investigación de la Universidad de Sevilla HUM-632 "proyecto, progreso, arquitectura" y tiene por objetivo compartir y debatir sobre investigación en arquitectura. Es una publicación científica con periodicidad semestral, en formato papel y digital, que publica trabajos originales que no hayan sido publicados anteriormente en otras revistas. Queda establecido el sistema de arbitraje para la selección de artículos a publicar mediante dos revisores externos -sistema doble ciego- siguiendo los protocolos habituales para publicaciones científicas seriadas. Los títulos, resúmenes y palabras clave de los artículos se publican también en lengua inglesa.

"proyecto, progreso, arquitectura" presenta una estructura clara, sencilla y flexible. Trata todos los temas relacionados con la teoría y la práctica del proyecto arquitectónico. Las distintas "temáticas abiertas" que componen nuestra línea editorial, son las fuentes para la conjunción de investigaciones diversas.

La revista va dirigida a arquitectos, estudiantes, investigadores y profesionales relacionados con el proyecto y la realización de la obra de arquitectura.

Our journal, "proyecto, progreso, arquitectura", founded in 2010, is an initiative of the Research Group HUM-632 of the University of Seville and its objective is the sharing and debating of research within architecture. This six-monthly scientific publication, in paper and digital format, publishes original works that have not been previously published in other journals. The article selection process consists of a double blind system involving two external reviewers, following the usual protocols for serial scientific publications. The titles, summaries and key words of articles are also published in English.

"proyecto, progreso, arquitectura" presents a clear, easy and flexible structure. It deals with all the subjects relating to the theory and the practise of the architectural project. The different "open themes" that compose our editorial line are sources for the conjunction of diverse investigations.

The journal is directed toward architects, students, researchers and professionals related to the planning and the accomplishment of the architectural work

\section{SISTEMA DE ARBITRAJE}

EVALUACIÓN EXTERNA POR PARES Y ANÓNIMA.

El Consejo Editorial de la revista, una vez comprobado que el artículo cumple con las normas relativas a estilo y contenido indicadas en las directrices para los autores, remitirá el artículo a dos expertos revisores anónimos dentro del campo específico de investigación y crítica de arquitectura, según el modelo doble ciego.

Basándose en las recomendaciones de los revisores, el director de la revista comunicará a los autores el resultado motivado de la evaluación por correo electrónico, en la dirección que éstos hayan utilizado para enviar el artículo. El director comunicará al autor principal el resultado de la revisión (publicación sin cambios; publicación con correcciones menores; publicación con correcciones importantes; no aconsejable para su publicación), así como las observaciones y comentarios de los revisores.

Si el manuscrito ha sido aceptado con modificaciones, los autores deberán reenviar una nueva versión del artículo, atendiendo a las demandas y sugerencias de los evaluadores externos. Si lo desean, los autores pueden aportar también una carta al Consejo Editorial en la que indicarán el contenido de las modificaciones del artículo. Los artículos con correcciones importantes podrán ser remitidos al Consejo Asesor y/o Científico para verificar la validez de las modificaciones efectuadas por el autor.

\section{EXTERNAL ANONYMOUS PEER REVIEW.}

When the Editorial Board of the magazine has verified that the article fulfils the standards relating to style and content indicated in the instructions for authors, the article will be sent to two anonymous experts, within the specific field of architectural investigation and critique, for a double blind review.

The Director of the magazine will communicate the result of the reviewers' evaluations, and their recommendations, to the authors by electronic mail, to the address used to send the article. The Director will communicate the result of the review (publication without changes; publication with minor corrections; publication with significant corrections; its publication is not advisable), as well as the observations and comments of the reviewers, to the main author.

If the manuscript has been accepted with modifications, the authors will have to resubmit a new version of the article, addressing the requirements and suggestions of the external reviewers. If they wish, the authors can also send a letter to the Editorial Board, in which they will indicate the content of the modifications of the article. The articles with significant corrections can be sent to Advisory and/or Scientific Board for verification of the validity of the modifications made by the author.

\section{INSTRUCCIONES A AUTORES PARA LA REMISIÓN DE ARTÍCULOS}

NORMAS DE PUBLICACIÓN

Instrucciones a autores: extensión máxima del artículo, condiciones de diseño -márgenes, encabezados, tipo de letra, cuerpo del texto y de las citas-, composición primera página, forma y dimensión del título y del autor, condiciones de la reseña biográfica, del resumen, de las palabras claves, de las citas, de las imágenes -numeración en texto, en pié de imágenes, calidad de la imagen y autoría o procedencia- y de la bibliografía en http://www.proyectoprogresoarquitectura.com

PUBLICATION STANDARDS

Instructions to authors: maximum length of the article, design conditions (margins, headings, font, body of the text and quotations), composition of the front page, form and size of the title and the name of the author, conditions of the biographical review, the summary, key words, quotations, images (text numeration, image captions, image quality and authorship or origin) and of the bibliography in http:// www.proyectoprogresoarquitectura.com 


\section{SERVICIOS DE INFORMACIÓN}

\section{CALIDAD EDITORIAL}

La Editorial Universidad de Sevilla cumple los criterios establecidos por la Comisión Nacional Evaluadora de la Actividad Investigadora para que lo publicado por el mismo sea reconocido como "de impacto" (Ministerio de Ciencia e Innovación, Resolución 18939 de 11 de noviembre de 2008 de la Presidencia de la CNEAl, Apéndice I, BOE n 282, de 22.11.08).

La Editorial Universidad de Sevilla forma parte de la U.N.E. (Unión de Editoriales Universitarias Españolas) ajustándose al sistema de control de calidad que garantiza el prestigio e internacionalidad de sus publicaciones.

PUBLICATION QUALITY

The Editorial Universidad de Sevilla fulfils the criteria established by the National Commission for the Evaluation of Research Activity (CNEAl) so that its publications are recognised as "of impact" (Ministry of Science and Innovation, Resolution 18939 of 11 November 2008 on the Presidency of the CNEAl, Appendix I, BOE No 282, of 22.11.08).

The Editorial Universidad de Sevilla operates a quality control system which ensures the prestige and international nature of its publications, and is a member of the U.N.E. (Unión de Editoriales Universitarias Españolas-Union of Spanish University Publishers).

Los contenidos de la revista PROYECTO, PROGRESO, ARQUITECTURA aparece en:

\section{bases de datos: indexación}

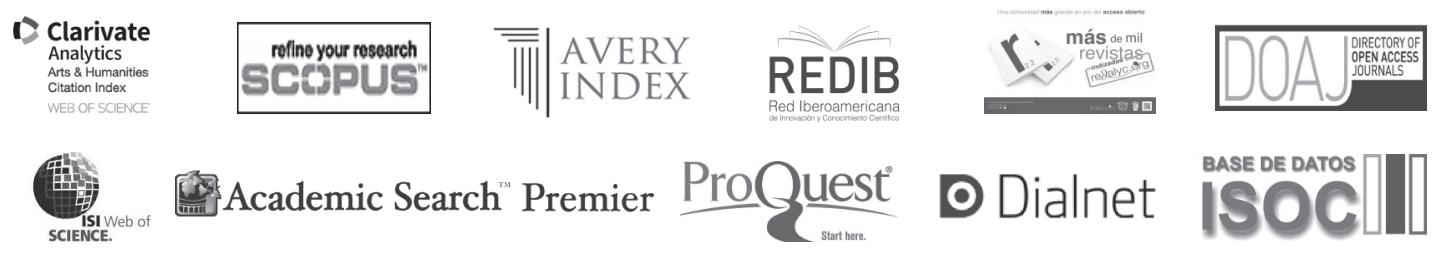

WoS. Arts \& Humanities Citation Index

WoS. ESCl - Emerging Sources Citation Index

SCOPUS

AVERY. Avery Index to Architectural Periodicals

REBID. Red Iberoamericana de Innovación y Conocimiento Científico

REDALYC. Red de Revistas Científicas de América Latina y el Caribe, España y Portugal.

EBSCO. Fuente Académica Premier

EBSCO. Art Source

DOAJ, Directory of Open Access Journals

PROQUEST (Arts \& Humanities, full text)

DIALNET

ISOC (Producida por el CCHS del CSIC)

DRIJ. Directory of Research Journals Indexing

SJR (2017): 0.100, H index: 2

\section{catalogaciones: criterios de calidad}

RESH (Revistas Españolas de Ciencias Sociales y Humanidades).

Catálogos CNEAI (16 criterios de 19). ANECA (18 criterios de 21). LATINDEX (35 criterios sobre 36).

DICE (CCHS del CSIC, ANECA).

MIAR, Matriu d'Informació per a l'Avaluació de Revistes. IDCS 2018: 10,300. Campo ARQUITECTURA

CLASIFICACIÓN INTEGRADA DE REVISTAS CIENTÍFICAS (CIRC-CSIC): B

CARHUS 2014: B

ERIHPLUS

SCIRUS, for Scientific Information.

ULRICH'S WEB, Global Serials Directory.

ACTUALIDAD IBEROAMERICANA.

catálogos on-line bibliotecas notables de arquitectura:

CLIO. Catálogo on-line. Columbia University. New York

HOLLIS. Catálogo on-line. Harvard University. Cambridge. MA

SBD. Sistema Bibliotecario e Documentale. Instituto Universitario di Architettura di Venezia

OPAC. Servizi Bibliotecari di Ateneo. Biblioteca Centrale. Politecnico di Milano

COPAC. Catálogo colectivo (Reino Unido)

SUDOC. Catálogo colectivo (Francia)

ZBD. Catálogo colectivo (Alemania)

REBIUN. Catálogo colectivo (España)

OCLC. WorldCat (Mundial) 


\section{DECLARACIÓN ÉTICA SOBRE PUBLICACIÓN Y MALAS PRÁCTICAS}

La revista PROYECTO, PROGRESO ARQUITECTURA (PPA) está comprometida con la comunidad académica en garantizar la ética y calidad de los artículos publicados. Nuestra revista tiene como referencia el Código de Conducta y Buenas Prácticas que, para editores de revistas científicas define el COMITÉ DE ÉTICA DE PUBLICACIONES (COPE).

Así nuestra revista garantiza la adecuada respuesta a las necesidades de los lectores y autores, asegurando la calidad de lo publicado, protegiendo y respetando el contenido de los artículos y la integridad de los mismo. El Consejo Editorial se compromete a publicar las correcciones, aclaraciones, retracciones y disculpas cuando sea preciso.

En cumplimiento de estas buenas prácticas, la revista PPA tiene publicado el sistema de arbitraje que sigue para la selección de artículos así como los criterios de evaluación que deben aplicar los evaluadores externos -anónimos y por pares, ajenos al Consejo Editorial-. La revista PPA mantiene actualizado estos criterios, basados exclusivamente en la relevancia científica del artículo, originalidad, claridad y pertinencia del trabajo presentado.

Nuestra revista garantiza en todo momento la condifencialidad del proceso de evaluación: el anonimato de los evaluadores y de los autores; el contenido evaluado; el informe razonado emitidos por los evaluadores y cualquier otra comunicación emitida por los consejos editorial, asesor y científico si así procediese.

Igualmente queda afectado de la máxima confidencialidad las posibles aclaraciones, reclamaciones o quejas que un autor desee remitir a los comités de la revista o a los evaluadores del artículo.

La revista PROYECTO, PROGRESO, ARQUITECTURA (PPA) declara su compromiso por el respecto e integridad de los trabajos ya publicados. Por esta razón, el plagio está estrictamente prohibido y los textos que se identifiquen como plagio o su contenido sea fraudulento, serán eliminados o no publicados de la revista PPA. La revista actuará en estos casos con la mayor celeridad posible. Al aceptar los términos y acuerdos expresados por nuestra revista, los autores han de garantizar que el artículo y los materiales asociados a él son originales o no infringen derechos de autor. También los autores tienen que justificar que, en caso de una autoría compartida, hubo un consenso pleno de todos los autores afectados y que no ha sido presentado ni publicado con anterioridad en otro medio de difusión.

\section{ETHICS STATEMENT ON PUBLICATION AND BAD PRACTICES}

PROYECTO, PROGRESO ARQUITECTURA (PPA) makes a commitment to the academic community by ensuring the ethics and quality of its published articles. As a benchmark, our journal uses the Code of Conduct and Good Practices which, for scientific journals, is defined for editors by the PUBLICATION ETHICS COMMITTEE (COPE).

Our journal thereby guarantees an appropriate response to the needs of readers and authors, ensuring the quality of the published work, protecting and respecting the content and integrity of the articles. The Editorial Board will publish corrections, clarifications, retractions and apologies when necessary.

In compliance with these best practices, PPA has published the arbitration system that is followed for the selection of articles as well as the evaluation criteria to be applied by the anonymous, external peer-reviewers. PPA keeps these criteria current, based solely on the scientific importance, the originality, clarity and relevance of the presented article.

Our journal guarantees the confidentiality of the evaluation process at all times: the anonymity of the reviewers and authors; the reviewed content; the reasoned report issued by the reviewers and any other communication issued by the editorial, advisory and scientific boards as required.

Equally, the strictest confidentiality applies to possible clarifications, claims or complaints that an author may wish to refer to the journal's committees or the article reviewers.

PROYECTO, PROGRESO ARQUITECTURA (PPA) declares its commitment to the respect and integrity of work already published. For this reason, plagiarism is strictly prohibited and texts that are identified as being plagiarized, or having fraudulent content, will be eliminated or not published in PPA. The journal will act as quickly as possible in such cases. In accepting the terms and conditions expressed by our journal, authors must guarantee that the article and the materials associated with it are original and do not infringe copyright. The authors will also have to warrant that, in the case of joint authorship, there has been full consensus of all authors concerned and that the article has not been submitted to, or previously published in, any other media. 



\section{arquitectura y espacio-soporte}

índice

editorial

LA ARQUITECTURA SALE A ESCENA / ARCHITECTURE EMERGES ON THE SCENE

Amadeo Ramos-Carranza; Rosa María Añón-Abajas - (Dol: http://dx.doi.org/10.12795/ppa.2018.119.12)

entre líneas

SVERRE FEHN: EL LUGAR COMO SOPORTE / SVERRE FEHN: THE PLACE AS A SUPPORT

Antonio Millán Gómez - (DOl: http://dx.doi.org/10.12795/ppa.2018.i19.01)

artículos

CENTRAAL BEHEER: LOS LÍMITES DEL ESTRUCTURALISMO EN LA CONFIGURACIÓN DE UN ESPACIO-SOPORTE / CENTRAAL BEHEER: THE LIMITS OF STRUCTURALISM IN THE CONFIGURATION OF A SUPPORT-SPACE

Rebeca Merino del Río; Julio Grijalba Bengoetxea - (Dol: http://dx.doi.org/10.12795/ppa.2018.119.02)

EL CONCEPTO DE LOW ROAD DE STEWART BRAND COMO FUNDAMENTO DE ESTRATEGIAS PARA LA ADAPTABILIDAD DE LOS ESPACIOS EN LA VIVIENDA CONTEMPORÁNEA / STEWART BRAND'S CONCEPT OF LOW ROAD AS A BASIS FOR STRATEGIES AND ADAPTABILITY OF SPACES IN COMTEMPORARY HOUSING

José Luis Bezos Alonso - (DOl: http://dx.doi.org/10.12795/ppa.2018.119.03)

OBJETOS EN LA CIUDAD. DONALD JUDD Y EL PROYECTO PARA LA CALLE STEINBERGGASSE DE WINTERTHUR / OBJECTS IN THE CITY. DONALD JUDD AND THE PROJECT FOR THE STEINBERGGASSE STREET IN WINTERTHUR

Pablo Llamazares Blanco; Fernando Zaparaín Hernández; Jorge Ramos Jular - (Dol: http://dx.doi.org/10.12795/ppa.2018.119.04)

DE LA WIDOW'S WALK A SECURITY. UNA INTERPRETACIÓN SOBRE LAS MASQUES DE JOHN HEJDUK / FROM THE WIDOW'S WALK TO SECURITY. AN INTERPRETATION ON THE MASQUES OF JOHN HEJDUK

Carlos Barberá Pastor - (Dol: http://dx.doi.org/10.12795/ppa.2018.119.05)

THE WEATHER PROJECT: DESPLAZAMIENTOS, ANDAMIAJES Y MODELOS METEOROLÓGICOS PARA UNA EVALUACIÓN CRÍTICA DEL ESCENARIO PÚBLICO / THE WEATHER PROJECT: DISPLACEMENTS, SCAFFOLDING AND METEOROLOGICAL MODELS FOR A CRITICAL EVALUATION OF THE PUBLIC DISPLAY

Tomás García Piriz - (Dol: http://dx.doi.org/10.12795/ppa.2018.i19.06)

EL ESPACIO DE LA EXPERIENCIA EN LAS ARQUITECTURAS DE RICHARD HAMILTON / THE SPACE OF EXPERIENCE IN THE ARCHITECTURE OF RICHARD HAMILTON

Luz Paz-Agras - (Dol: http://dx.doi.org/10.12795/ppa.2018.i19.07)

JAMES STIRLING Y EL PROYECTO DE LA TATE GALLERY EN ALBERT DOCK, LIVERPOOL, 1982-88 / JAMES STIRLING AND THE TATE GALLERY PROJECT IN ALBERT DOCK, LIVERPOOL, 1982-88 Eusebio Alonso García - (Dol: http://dx.doi.org/10.12795/ppa.2018.i19.08)

reseña bibliográfica TEXTOS VIVOS

JOHN HEJDUK: VICTIMAS

Gabriel Bascones de la Cruz - (Dol: http://dx.doi.org/10.12795/ppa.2018.119.09)

KEVIN LYNCH: THE IMAGE OF THE CITY

José Manuel López-Peláez - (DOl: http://dx.doi.org/10.12795/ppa.2018.19.10)

CARMEN DÍEZ MEDINA; JAVIER MONCLÚS FRAGA (EDS.): VISIONES URBANAS DE LA CULTURA DEL PLAN AL URBANISMO PAISAJÍSTICO

María Teresa Pérez-Cano - (Dol: http://dx.doi.org/10.12795/ppa.2018.i19.11) 

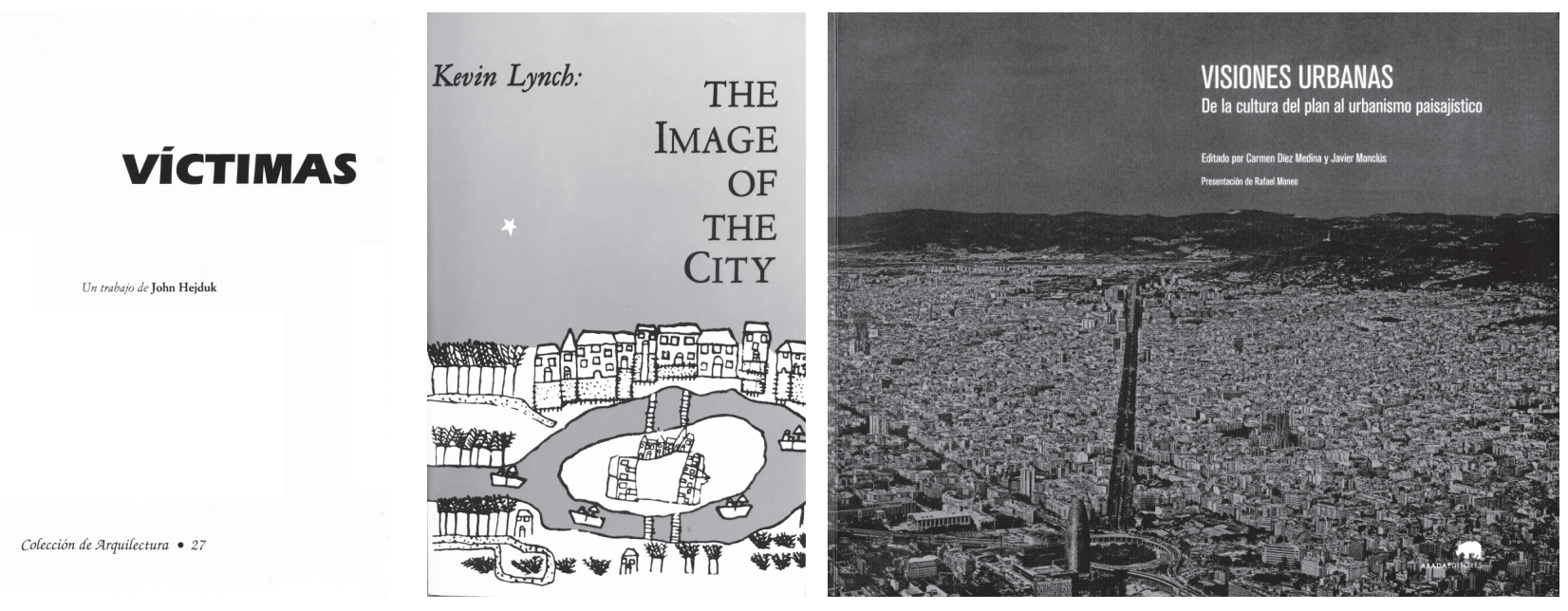

\section{reseña bibliográfica TEXTOS VIVOS}

Nuestra época está sometida a transformaciones hasta ahora insospechadas a cuya aparición no somos ajenos y que afectan a la forma de entender y practicar la arquitectura. El entendimiento y la acción en la nueva arquitectura no deben abordarse solo desde la racionalidad del proyecto sino desde la reconstrucción crítica de la memoria de nuestra cultura y de nuestra participación en ella a lo largo del tiempo y en la evolución de la sociedad.

Cada tiempo, y el nuestro también, decide qué arquitectos y cuáles textos y obras han de ser rescatados y recalificados como clásicos.

Mediante el diálogo con ellos, los arquitectos actuales nos alinearemos en la tradición arquitectónica de la que, hoy, de manera perentoria, no es posible ni razonable prescindir. PROYECTO, PROGRESO, ARQUITECTURA destina esta sección a realizar un repaso propositivo y abierto a esos textos. 


\title{
CARMEN DÍEZ MEDINA; JAVIER MONCLÚS FRAGA (EDS.): VISIONES URBANAS. DE LA CULTURA DEL PLAN AL URBANISMO PAISAJÍSTICO
}

\author{
Madrid: Abada Editores, 2017. 300 páginas, formato 24x30 cm. ISBN 978-84-161-6081-5
}

María Teresa Pérez-Cano

Dra. arquitecta. Profesora Titular de Universidad. Departamento de Urbanismo y Ordenación del Territorio. Escuela Técnica Superior de Arquitectura. Universidad de Sevilla. España.

Persona de contacto: tpcano@us.es

$V$ isiones urbanas. De la cultura del plan al urbanismo paisajístico (2017), publicado por Abada Editores, es el resultado de un ambicioso proyecto colectivo de ámbito internacional al amparo del programa comunitario Tempus, destinado a universidades de los países de los Balcanes Occidentales, Asia Central, Este y Sur de Europa, cuyo objetivo es alcanzar la convergencia con el sistema universitario europeo derivado del Proceso de Bolonia. En el caso que nos ocupa, participaron universidades de Bulgaria, Francia, Italia, Portugal, Reino Unido, Ucrania y España, más en concreto la Universidad de Zaragoza. El proyecto financiado tenía por título Architecture and Sustainable Development based on EcoHumanistic Principles \& Advanced Technologies whithout Losing Identity (SEHUD). Carmen Díez Medina y Javier Monclús actúan como editores de la presente publicación.

Es por ello por lo que el libro que se reseña cubre un amplio panorama internacional, que comienza con el Plan de Chicago de 1909, aunque referentes anteriores, como la ciudad jardín de Howard (1898), los principios artísticos de Sitte (1889) o el viejo ensanche de Cerdá (1859) subyacen como verdaderos inicios. Bajo una cuidada maquetación y un nutrido repertorio gráfico, mayoritariamente en color, a lo largo de treinta y dos ensayos organizados en cuatro secciones, podemos recorrer una gran parte de la producción urbanística del siglo XX hasta prácticamente nuestros días.

Prologado por Rafael Moneo, de sus once autores, incluidos los editores, cabe señalar que, salvo una profesora del Politécnico de Milán, todos forman parte del equipo docente de la joven Escuela de Ingeniería y Arquitectura (EINA), donde imparten clases en las áreas de urbanismo, composición arquitectónica y proyectos. Ello nos habla de la capacidad de los editores para aunar esfuerzos y de crear el oportuno caldo de cultivo que tiene como brillante resultado la publicación que nos ocupa.

Los textos planteados pueden tener una fuerte vocación docente, casi de manual para los alumnos de Arquitectura, pero entendemos que también resultarán de gran interés para arquitectos de distintas generaciones que se quieran poner al día, desde una nueva mirada, con el pasado reciente de la tradición urbanística y, por supuesto, en gran medida, con lo que se está produciendo en alguna de las grandes ciudades del panorama mundial. Cada sección se divide en ocho artículos de seis páginas, incluida la bibliografía, a los que se suman dos más, con ejemplos paralelos derivados del propio ensayo.

La primera sección, "Culturas y tradiciones urbanísticas", propone unas bases teóricas, en cierta medida, clásicas. La segunda, "Otros urbanismos y proyectos urbanos", introduce temas y cuestiones que han estado en el debate de la disciplina durante las últimas décadas del siglo XX, fundamentalmente desde la visión europea. "Nuevas estrategias y planes urbanísticos", la tercera sección, incorpora la globalización con ejemplos mayoritariamente asiáticos, americanos y centroeuropeos. Finalmente, "Urbanismo paisajístico" propone introducirnos en una de las corrientes actuales que están adquiriendo más fuerza, donde el peso de los ejemplos europeos y españoles es más significativo.

Especialmente interesante resulta para su estudio el índice onomástico que acompaña a los textos al final del libro. Este nos permite profundizar en el análisis de los contenidos, recorriendo desde sus numerosas entradas los autores, lugares y temáticas tratadas en los distintos artículos. Casi como si de un juego se tratara, podemos comprobar el peso que los autores le dan a los distintos casos de estudio tratados. En Europa, Londres es sin duda la ciudad más citada en el libro, con cuarenta y siete entradas, seguida de Berlín, con cuarenta y cuatro, París, con cuarenta, y Ámsterdam, con veintidós. Fuera del viejo continente es Nueva York, con quince entradas, la ciudad con más referencias. En España, la más citada es Barcelona, con treinta y siete entradas, seguida de Madrid, con veinticuatro, y Zaragoza, con diecinueve. La presencia de ejemplos del resto de ciudades del país, salvo Vitoria, con seis entradas, es testimonial o casi inexistente. 
Por citar a Andalucía, solamente hay una referencia a la Expo del 92 de Sevilla, sin información planimétrica. La experiencia como Paisaje Cultural de la Ensenada de Bolonia, por ejemplo, hubiese encajado plenamente en la cuarta sección.

En cuanto a los apoyos teóricos, autores, intelectuales y movimientos que son tomados como referencias conceptuales -ya clásicas o nuevas aperturas-, la presencia más recurrente en los distintos ensayos es, sin duda, la figura de Peter Hall, citado en treinta y seis ocasiones. A cierto trecho le siguen los CIAM, con veintitrés, James Corner (Field Operations) y Le Corbusier, con veintiuno. A más distancia, son influyentes los Team X y Rem Koolhaas, con trece. Jane Jacobs, Lewis Mumford y Anthony Sutcliffe son citados en doce ocasiones y Michael Hebbert y Rafael Moneo en once. Los clásicos Howard, Lynch y Cerdá tienen diez entradas, McHarg y Tafuri nueve, Castells, Desvigne, Haussmann, Lefebvre, Olmsted y Sieverts acumulan ocho, en tanto Bakema, Berman, Portas, Rowe y Woods aparecen en siete ocasiones y Abercrombie, Architekten CIE, Batlle, Geddes, Gravagnuolo, Foster, López de Lucio, M. Solà Morales, Sitte, Waldheim, West 8 y Wright lo hacen en seis. Finalmente, cierran este apartado de los más consultados Banham, Berger, Candilis, Choay, Mostafavi, Corajoud, Cullen, Debord, Fishman, Holling, Lister, Rogers, Secchi y Walker, con cinco menciones. Aunque, ciertamente, el repertorio crítico es más amplio en autores, se evidencia en el global el peso de los norteamericanos.

Podemos resaltar que la francesa Françoise Choay —aunque masculinizada como François_ es la única referencia femenina europea en este listado VIP. Entre las incómodas ausencias, destacan las de los españoles Rosa Barba, Pedro Bidagor, Fernando de Terán, Damián Quero, Carlos Sambricio o Carles Llop y las de los italianos Carlo Aymonino y Luigi Piccinato.

Si pensamos en materias y temáticas, el concepto escala es citado sesenta y dos ocasiones, tipologías en treinta y cuatro, y morfología en once, pero no hay entrada para rehabilitación, aunque sí para conceptos como recualificación, regeneración urbana o resiliencia. Existen entradas para ciudad central, ciudad difusa, ciudad dispersa, ciudad jardín, ciudad satélite, ciudades corporativas e incluso para ciudades resilientes, pero no para ciudad histórica — sí centros históricos— ni para ciudad patrimonial. Igual ocurre en cuanto a cómo se apellida el concepto "urbanismo", lo hay de posguerra, ecológico, funcionalista, moderno, paisajista, participativo, pero no desde una perspectiva de género.

Pero toda selección implica, sin duda, renuncias necesarias, aunque también ausencias intencionadas. Significa obligatoriamente dejar fuera actores, escenarios y temáticas, de ahí el propio título, Visiones urbanas.

Podríamos preguntarnos si los ejemplos tratados son los más representativos, si los lugares elegidos son los más emblemáticos, si las referidas ausencias están justificadas. Evidentemente, en eso consiste la responsabilidad de la propia autoría, incluso el derecho a crear opinión. Como se dice en la contraportada: "La sucesión de ensayos sobre temas y casos diversos no pretende establecer interpretaciones universales, sino destacar algunos episodios relevantes".

Para concluir esta invitación a la lectura de este imprescindible texto, señalaremos que, al no encontrar la entrada paisaje cultural, intencionadamente dejamos fuera del título de esta reseña las palabras de su enunciado, culturas y paisaje, quizás porque son las que pueden contener los conceptos más patrimoniales referidos a la mirada que depositamos sobre la ciudad y el territorio que la acoge. Probablemente sea la patrimonial la visión que echamos más en falta.

Solo cuando algo gusta mucho se tienen ganas de más. Lo que a nuestro juicio entendemos como ausencias representa una declaración de intenciones, una llamada a seguir sumando desde Andalucía otras visiones urbanas. 

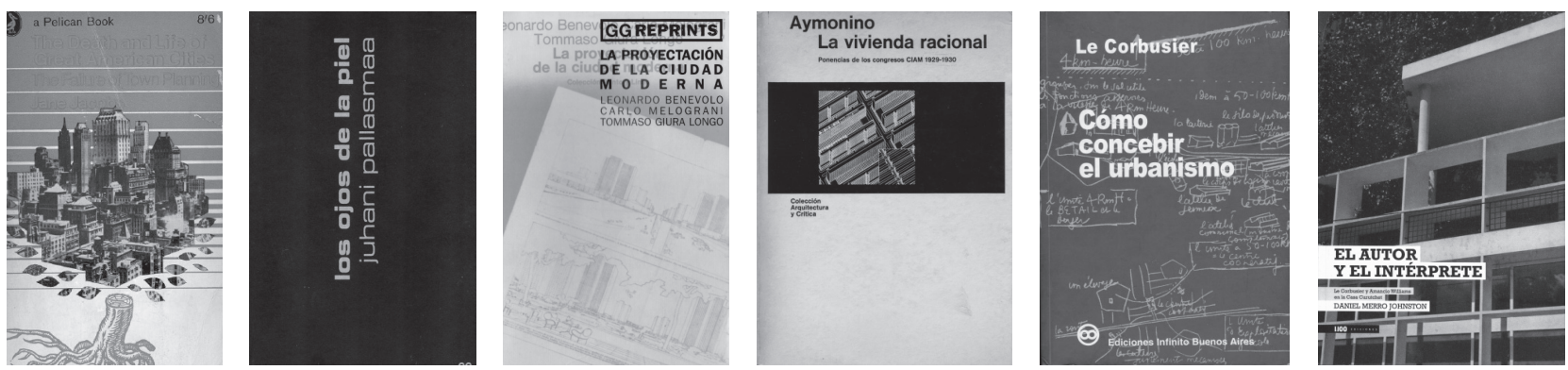

PPA N04: Jane Jacobs: MUERTE Y VIDA DE LAS GRANDES CIUDADES - Juhani Pallasmaa: LOS OJOS DE LA PIEL. LA ARQUITECTURA DE LOS SENTIDOS - Leonardo Benevolo et alt: LA PROYECTACIÓN DE LA CIUDAD MODERNA / PPA N05: Carlo Aymonino: LA VIVIENDA RACIONAL. PONENCIAS DE LOS CONGRESOS CIAM - Le Corbusier: CÓMO CONCEBIR EL URBANISMO - Daniel Merro Johnston: EL AUTOR Y EL INTÉRPRETE. LE CORBUSIER Y AMANCIO WILLIMAS EN LA CASA CURUTCHET
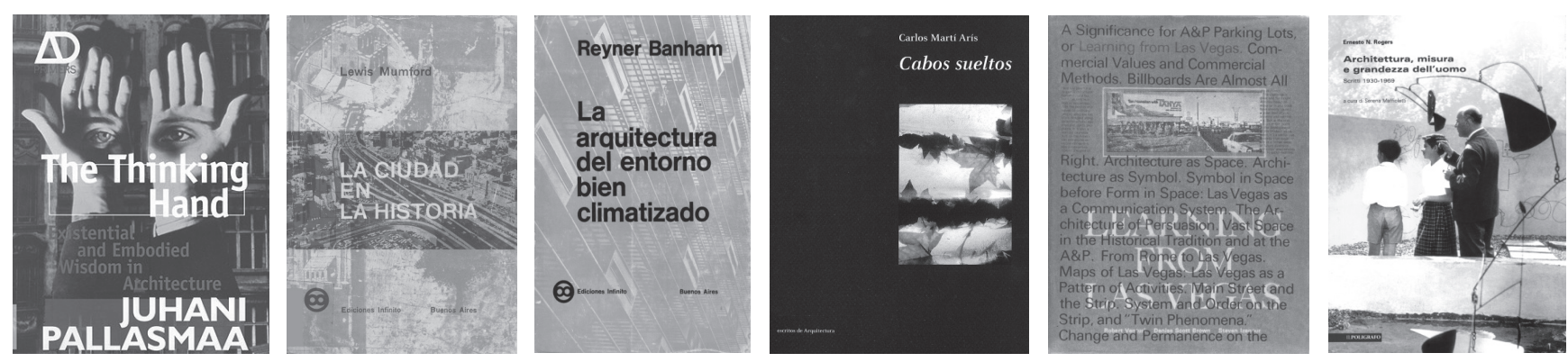

PPA N06: Juhani Pallasmaa: THE THINKING HAND: EXISTENTIAL AND EMBOIDIED WISDOM IN ARCHITECTURE - Lewis Mumford: LA CIUDAD EN LA HISTORIA. SUS ORÍGENES, TRANSFORMACIONES Y PERSPECTIVAS - Reyner Banham: LA ARQUITECTURA DEL ENTORNO BIEN CLIMATIZADO / PPA N07: Carlos Martí Arís: CABOS SUELTOS / PPA N08: Robert Venturi, Denise Scott Brown y Steven Izenour: LEARNING FROM LAS VEGAS / Serena Mafioletti: ARCHITTETURA, MISURA E GRANDEZA DELL'UOMO. SCRITTI 1930-1969
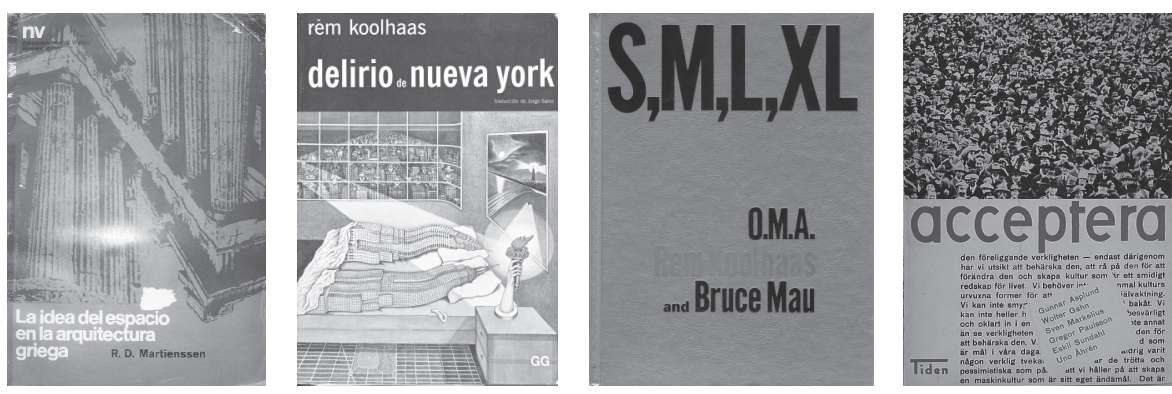

PPA N09: R. D. Martienssen: LA IDEA DEL ESPACIO EN LA ARQUITECTURA GRIEGA / PPA N10: Rem Koolhaas: SMALL, MEDIUM, LARGE, EXTRA-LARGE - Rem Koolhaas: DELIRIO DE NUEVA YORK. UN MANIFIESTO RETROACTIVO PARA MANHATTAN / PPA N11: G. Asplund, W. Gahn, S. Markelius, G. Paulsson, E. Sundahl, U. Åhrén: ACCEPTERA
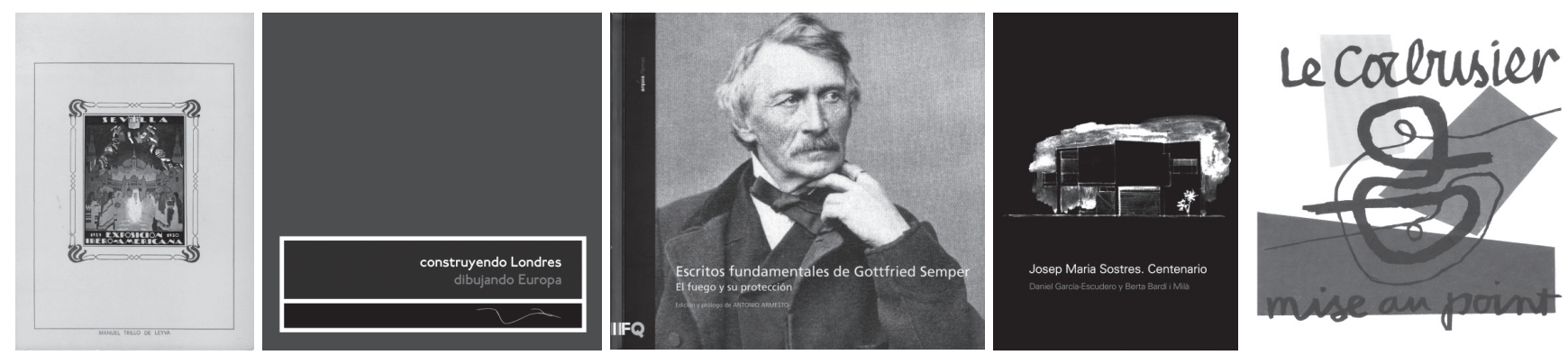

PPA N12: Manuel Trillo de Leyva: LA EXPOSICIÓN IBEROAMERICANA: LA TRANSFORMACIÓN URBANA DE SEVILLA - Manuel Trillo de Leyva: CONSTRUYENDO LONDRES; DIBUJANDO EUROPA / PPA N13: Antonio Armesto (Ed. y Prol.): ESCRITOS FUNDAMENTALES DE GOTTFRIED SEMPER. EL FUEGO Y SU PROTECCIÓN - Daniel García-Escudero y Berta Bardí i milà (Comps.): JOSÉ MARÍA SOSTRES. CENTENARIO - Jorge Torres Cueco (Trad.): LE CORBUSIER. MISE AU POINT 

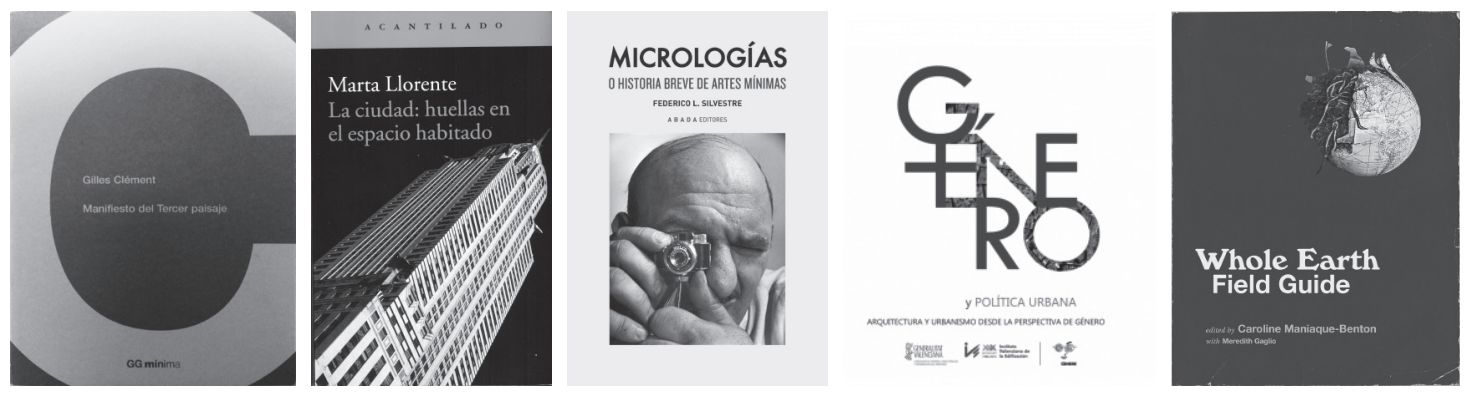

PPA N14: Gilles Clément: MANIFIESTO DEL TERCER PAISAJEERA - Marta Llorente Díaz: LA CIUDAD: HUELLAS EN EL ESPACIO HABITADO / PPA N15: Federico López Silvestre: MICROLOGÍAS O BREVE HISTORIA DE ARTES MÍNIMAS / PPA N16: Begoña Serrano Lanzarote; Carolina Mateo Cecilia; Alberto Rubio Garrido (ED.): GÉNERO Y POLÍTICA URBANA. ARQUITECTURA Y URBANISMODESDE LA PERSPECTIVA DE GÉNERO - Caroline Maniaque-Benton with Merodith Gaglio (EDS.) WHOLE EARTH FIELD GUIDE
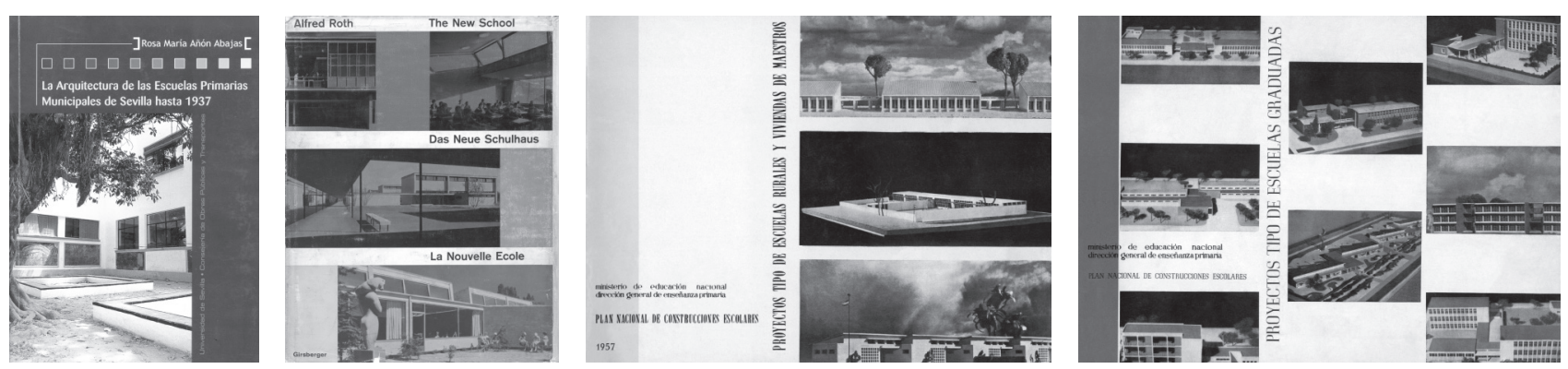

PPA N17: Rosa María Añón Abajas: LA ARQUITECTURA DE LAS ESCUELAS PRIMARIAS MUNICIPALES DE SEVILLA HASTA 1937 - Alfred Roth: THE NEW SCHOOL - PLAN NACIONAL DE CONSTRUCCIONES ESCOLARES (VOLUMEN I) PROYECTOS TIPO DE ESCUELAS RURALES Y VIVIENDAS DE MAESTROS. PLAN NACIONAL DE CONSTRUCCIONES ESCOLARES (VOLUMNE II) PROYECTOS TIPO DE ESCUELAS GRADUADAS-
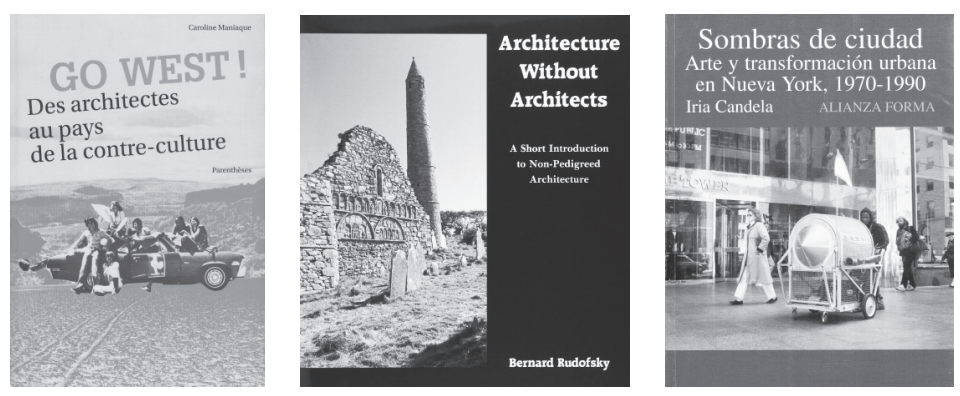

PPA N18: Caroline Maniaque: GO WEST! DES ARCHITECTES AU PAYS DE LA CONTRE-CULTURE - Bernard Rudofsky: ARCHITECTURE WITHOUT ARCHITECTS. A SHORT INTRODUCTION TO NON-PEDIGREED ARCHITECTURE - Iria Candela: SOMBRES DE CIUDAD. ARTE Y TRANSFORMACIÓN URBANA EN NUEVA YORK 1970-1990

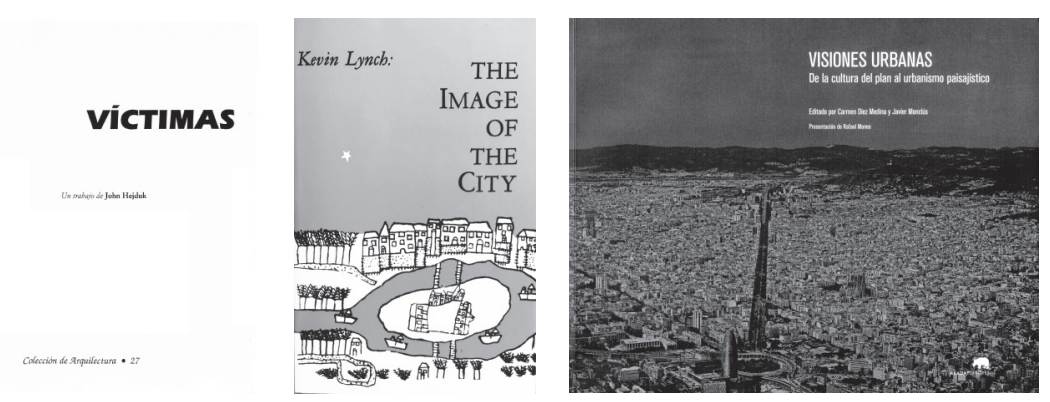

PPA N19: John Hejduk: VíCTIMAS - Kevin Lynch: THE IMAGE OF THE CITY - Carmen Díez Medina; Javier Monclús Fraga (eds): VISIONES URBANAS DE LA CULTURA DEL PLAN AL URBANISMO PAISAJÍSTICO 
- EDITORIAL • LA ARQUITECTURA SALE A ESCENA / ARCHITECTURE EMERGES ON THE SCENE. Amadeo Ramos-Carranza • ENTRE LÍNEAS • SVERRE FEHN: EL LUGAR COMO SOPORTE / SVERRE FEHN: THE PLACE AS A SUPPORT. Antonio Millán Gómez • ARTÍCULOS • CENTRAAL BEHEER: LOS LÍMITES DEL ESTRUCTURALISMO EN LA CONFIGURACIÓN DE UN ESPACIO-SOPORTE / CENTRAAL BEHEER: THE LIMITS OF STRUCTURALISM IN THE CONFIGURATION OF A SUPPORT-SPACE. Rebeca Merino del Río; Julio Grijalba Bengoetxea • EL CONCEPTO DE LOW ROAD DE STEWART BRAND COMO FUNDAMENTO DE ESTRATEGIAS PARA LA ADAPTABILIDAD DE LOS ESPACIOS EN LA VIVIENDA CONTEMPORÁNEA / STEWART BRAND'S CONCEPT OF LOW ROAD AS A BASIS FOR STRATEGIES AND ADAPTABILITY OF SPACES IN COMTEMPORARY HOUSING. JOsé LUIS BezOS Alonso • OBJETOS EN LA CIUDAD. DONALD JUDD Y EL PROYECTO PARA LA CALLE STEINBERGGASSE DE WINTERTHUR / OBJECTS IN THE CITY. DONALD JUDD AND THE PROJECT FOR THE STEINBERGGASSE STREET IN WINTERTHUR . Pablo Llamazares Blanco; Fernando Zaparaín Hernández; Jorge Ramos Jular • DE LA WIDOW'S WALK A SECURITY. UNA INTERPRETACIÓN SOBRE LAS MASQUES DE JOHN HEJDUK / FROM THE WIDOW'S WALK TO SECURITY. AN INTERPRETATION ON THE MASQUES OF JOHN HEJDUK. Carlos Barberá Pastor • THE WEATHER PROJECT: DESPLAZAMIENTOS, ANDAMIAJES Y MODELOS METEOROLÓGICOS PARA UNA EVALUACIÓN CRÍTICA DEL ESCENARIO PÚBLICO / THE WEATHER PROJECT: DISPLACEMENTS, SCAFFOLDING AND METEOROLOGICAL MODELS FOR A CRITICAL EVALUATION OF THE PUBLIC DISPLAY. Tomás García Piriz • EL ESPACIO DE LA EXPERIENCIA EN LAS ARQUITECTURAS DE RICHARD HAMILTON / THE SPACE OF EXPERIENCE IN THE ARCHITECTURE OF RICHARD HAMILTON. Luz Paz-Agras • JAMES STIRLING Y EL PROYECTO DE LA TATE GALLERY EN ALBERT DOCK, LIVERPOOL, 1982-88 / JAMES STIRLING AND THE TATE GALLERY PROJECT IN ALBERT DOCK, LIVERPOOL, 1982-88. Eusebio Alonso García • RESEÑAS BIBLIOGRÁFICAS • JOHN HEJDUK: VICTIMAS. Gabriel Bascones de la CrUZ • KEVIN LYNCH: THE IMAGE OF THE CITY. José Manuel López-Peláez • CARMEN DíEZ MEDINA; JAVIER MONCLÚS (EDS.): VISIONES URBANAS DE LA CULTURA DEL PLAN AL URBANISMo PAISAJístico. María Teresa Pérez-Cano
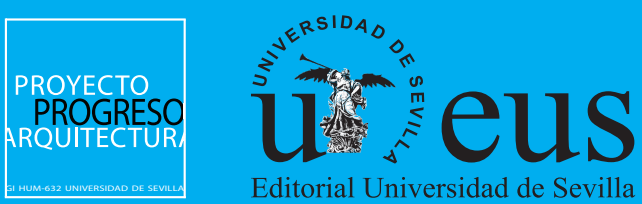